\title{
Front Matter: Volume 9492
}

, "Front Matter: Volume 9492," Proc. SPIE 9492, Advanced Photon Counting Techniques IX, 949201 (28 May 2015); doi: 10.1117/12.2199548

SPIE Event: SPIE Sensing Technology + Applications, 2015, Baltimore, MD, United SPIE. States 


\title{
PROCEEDINGS OF SPIE
}

\section{Advanced Photon Counting Techniques IX}

\author{
Mark A. Itzler \\ Joe C. Campbell \\ Editors
}

22-23 April 2015

Baltimore, Maryland, United States

Sponsored and Published by

SPIE 
The papers included in this volume were part of the technical conference cited on the cover and title page. Papers were selected and subject to review by the editors and conference program committee. Some conference presentations may not be available for publication. The papers published in these proceedings reflect the work and thoughts of the authors and are published herein as submitted. The publisher is not responsible for the validity of the information or for any outcomes resulting from reliance thereon.

Please use the following format to cite material from this book:

Author(s), "Title of Paper," in Advanced Photon Counting Techniques IX, edited by Mark A. Itzler, Joe C. Campbell, Proceedings of SPIE Vol. 9492 (SPIE, Bellingham, WA, 2015) Article CID Number.

ISSN: 0277-786X

ISBN: '9781628416084

Published by

SPIE

P.O. Box 10, Bellingham, Washington 98227-0010 USA

Telephone +1 3606763290 (Pacific Time) · Fax +1 3606471445

SPIE.org

Copyright (C) 2015, Society of Photo-Optical Instrumentation Engineers.

Copying of material in this book for internal or personal use, or for the internal or personal use of specific clients, beyond the fair use provisions granted by the U.S. Copyright Law is authorized by SPIE subject to payment of copying fees. The Transactional Reporting Service base fee for this volume is $\$ 18.00$ per article (or portion thereof), which should be paid directly to the Copyright Clearance Center (CCC), 222 Rosewood Drive, Danvers, MA 01923. Payment may also be made electronically through CCC Online at copyright.com. Other copying for republication, resale, advertising or promotion, or any form of systematic or multiple reproduction of any material in this book is prohibited except with permission in writing from the publisher. The CCC fee code is 0277-786X/15/\$18.00.

Printed in the United States of America.

Publication of record for individual papers is online in the SPIE Digital Library.

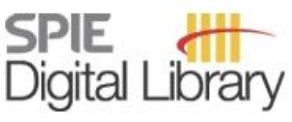

SPIEDigitalLibrary.org

Paper Numbering: Proceedings of SPIE follow an e-First publication model, with papers published first online and then in print. Papers are published as they are submitted and meet publication criteria. A unique citation identifier (CID) number is assigned to each article at the time of the first publication. Utilization of CIDs allows articles to be fully citable as soon as they are published online, and connects the same identifier to all online, print, and electronic versions of the publication. SPIE uses a six-digit CID article

numbering system in which:

- The first four digits correspond to the SPIE volume number.

- The last two digits indicate publication order within the volume using a Base 36 numbering system employing both numerals and letters. These two-number sets start with 00, 01, 02, 03, 04, $05,06,07,08,09,0 A, 0 B \ldots$ OZ, followed by 10-1Z, 20-2Z, etc.

The CID Number appears on each page of the manuscript. The complete citation is used on the first page, and an abbreviated version on subsequent pages. 


\title{
Contents
}

\author{
$\checkmark$ Authors \\ vii Conference Committee
}

SINGLE-PHOTON APPLICATIONS I

949202 Cutting the cord: toward wireless optical intensity interferometry (Invited Paper) [9492-1]

SINGLE-PHOTON APPLICATIONS II

949208 An optical receiver for the Lunar Laser Communication Demonstration based on photoncounting superconducting nanowires (Invited Paper) [9492-7]

949209 Single photon counting for space based quantum experiments [9492-8]

\section{SUPERCONDUCTING SINGLE-PHOTON DETECTORS}

$9492 \mathrm{OE} \quad$ Large-area NbN superconducting nanowire avalanche photon detectors with saturated detection efficiency [9492-13]

\section{SINGLE-PHOTON LIDAR I}

9492 ol Underwater depth imaging using time-correlated single photon counting [9492-17]

\section{SINGLE-PHOTON LIDAR II}

9492 OK Study of single photon counting for non-line-of-sight vision [9492-19]

$9492 \mathrm{OL} \quad$ Hybrid receiver system for single photon sensitive direct and coherent detection (Best Paper Award) [9492-20]

\section{GEIGER-MODE APDS}

$94920 \mathrm{M}$ Silicon Geiger-mode avalanche photodiode arrays for photon-starved imaging (Invited Paper) [9492-21]

$94920 \mathrm{~N}$ Gun muzzle flash detection using a single photon avalanche diode array in $0.18 \mu \mathrm{m}$ CMOS technology (Invited Paper) [9492-22] 
949200 Analysis and modeling of optical crosstalk in InP-based Geiger-mode avalanche photodiode FPAs [9492-23]

9492 OP Model of turn-on characteristics of InP-based Geiger-mode avalanche photodiodes suitable for circuit simulations [9492-24]

$94920 Q \quad$ Low noise InGaAs/InP single-photon negative feedback avalanche diodes: characterization and applications (Invited Paper) [9492-25]

NOVEL AVALANCHE DIODE SPDS

9492 OT Linear mode photon counting from visible to MWIR with $\mathrm{HgCdTe}$ avalanche photodiode focal plane arrays (Invited Paper, Best Paper Award) [9492-28] 


\title{
Authors
}

Numbers in the index correspond to the last two digits of the six-digit citation identifier (CID) article numbering system used in Proceedings of SPIE. The first four digits reflect the volume number. Base 36 numbering is employed for the last two digits and indicates the order of articles within the volume. Numbers start with 00, 01, 02, 03, 04, 05, 06, 07, 08, 09, 0A, OB...0Z, followed by 10-1Z, 20-2Z, etc.

\author{
Abshire, James, OT \\ Aull, Brian F., OM \\ Beck, Jeffrey, OT \\ Berggren, Karl K., OE \\ Boroson, Don M., 08 \\ Boso, Gianluca, $0 Q$ \\ Bratcher, Andrew, OL \\ Brouk, Igor, ON \\ Buller, Gerald S., Ol \\ Carpenter, Darren, OT \\ Chandrasekara, R., 09 \\ Chau, Quan, 00 \\ Cheng, C., 09 \\ Christnacher, Frank, OK \\ Dauler, Eric A., 08, 0E \\ Donnelly, Joseph, OP \\ Entwistle, Mark, 00 \\ Glennon, John, OL \\ Grein, Matthew E., 08, OE \\ Gudmundsen, Theodore J., OE \\ Horch, Elliott P., 02 \\ Hullin, Matthias B., OK \\ Itzler, Mark A., 00 \\ Jakobson, Claudio, ON \\ Jiang, Xudong, 00 \\ Jordy, George, OP \\ Kerman, Andrew J., 08 \\ Klein, Jonathan, OK \\ Kondratko, Piotr Konrad, OL \\ Korzh, Boris, $\mathrm{OQ}$ \\ Lane, Barry, OT \\ Laurenzis, Martin, OK \\ Ling, A., 09 \\ Lunghi, Tommaso, $0 Q$ \\ Maccarone, Aurora, 01 \\ Marsili, Francesco, OE \\ McCarthy, Aongus, 01 \\ McCaughan, Adam, OE \\ Merhav, Tomer, ON \\ Mitra, Pradip, OT \\ Moffat, James, 0 I \\ Molnar, Richard J., 08 \\ Murphy, Daniel V., 08 \\ Murphy, Ryan P., OE \\ Najafi, Faraz, OE \\ Nemirovsky, Yael, ON \\ Owens, Mark, 00 \\ Petillot, Yvan, ol \\ Piccione, Brian, 00
}

Ren, Ximing, 0 I

Robinson, Bryan S., 08

Romkey, Barry, 08

Savuskan, Vitali, ON

Scritchfield, Richard, OT

Shoham, Avi, ON

Skokan, Mark, OT

Slomkowski, Krystyna, 00

Sullivan, William, III, OT

Sun, Xiaoli, OT

Suni, Paul, OL

Tan, Y. C., 09

Tang, Z. K., 09

Velten, Andreas, OK

Wallace, Andy M., Ol

Warburton, Ryan E., Ol

Wildfever, C., 09

Willis, Matthew M., 08

Zbinden, Hugo, $O Q$ 
Proc. of SPIE Vol. $9492949201-6$

Downloaded From: https://www.spiedigitallibrary.org/conference-proceedings-of-spie on 26 Apr 2023 Terms of Use: https://www.spiedigitallibrary.org/terms-of-use 


\title{
Conference Committee
}

\author{
Symposium Chair
}

Wolfgang Schade, Clausthal University of Technology and Fraunhofer Heinrich-Hertz Institute (Germany)

Symposium Co-chair

Ming C. Wu, University of California, Berkeley (United States)

Conference Chair

Mark A. Itzler, Princeton Lightwave, Inc. (United States)

Conference Co-chair

Joe C. Campbell, University of Virginia (United States)

Conference Program Committee

Gerald S. Buller, Heriot-Watt University (United Kingdom)

Sergio Cova, Politecnico di Milano (Italy)

William H. Farr, Jet Propulsion Laboratory (United States)

Robert H. Hadfield, University of Glasgow (United Kingdom)

Majeed Hayat, The University of New Mexico (United States)

Michael A. Krainak, NASA Goddard Space Flight Center (United States)

Robert A. Lamb, SELEX Galileo Ltd. (United Kingdom)

K. Alex McIntosh, MIT Lincoln Laboratory (United States)

Alan L. Migdall, National Institute of Standards and Technology (United States)

Michael Wahl, PicoQuant GmbH (Germany)

Hugo Zbinden, University of Geneva (Switzerland)

Session Chairs

1 Single-Photon Applications I

Joe C. Campbell, University of Virginia (United States)

2 Keynote: SPDs and Quantum Sensing

Mark A. Itzler, Princeton Lightwave, Inc. (United States)

3 Single-Photon Applications II

Mark A. Itzler, Princeton Lightwave, Inc. (United States) 
4 Superconducting Single-Photon Detectors

Matthew E. Grein, MIT Lincoln Laboratory (United States)

5 Single-Photon LIDAR I

Mark A. Itzler, Princeton Lightwave, Inc. (United States)

6 Single-Photon LIDAR ॥

Mark A. Itzler, Princeton Lightwave, Inc. (United States)

7 Geiger-Mode APDs

K. Alex McIntosh, MIT Lincoln Laboratory (United States)

8 Novel Avalanche Diode SPDs

Alan L. Migdall, National Institute of Standards and Technology (United States) 